\title{
Chromatographic separations and characterization of bioactive secondary metabolites of Apergillus quadrilineatus (MH109538) fungal strain
}

\author{
Amina Bramki ${ }^{a^{*}}$, Edwin de Pauw ${ }^{\mathrm{b}}$, Meriem Frahtia $^{\mathrm{c}}$, Andrea McCann ${ }^{\mathrm{b}}$, Gabriel Mazzucchelli ${ }^{\mathrm{b}}$, Laid \\ Dehimat $^{a}$ \\ ${ }^{a}$ Laboratory of Mycology, Biotechnology and Microbial Activity, University of Mentouri Brothers-Constantine, Algeria \\ ${ }^{b}$ Mass Spectrometry Laboratory, Institute of Chemistry, Liège, Belgium \\ 'Laboratory of Medical Analysis, Public Establishment of Local Health, Mila, Algeria
}

Received 29th December 2019 / Accepted 8th June 2020

\begin{abstract}
In the interest of searching new antibiotic substances, the antibacterial effect of Aspergillus quadrilineatus fungal strain (MH109538) has been evaluated against sensitive bacteria (S. aureus, E. faecalis, B. subtilis and E. coli) and resistant bacteria (P. aeruginosa and $K$. pneumonia), following the disks technique. The obtained result confirms the capacity of this strain to produce antibacterial molecules. In order to analyze and characterize these bioactive metabolites present in the crude extract, which was fractionated by column chromatography. The fractions were then separated by thin-layer chromatography. The detected spots were sampled and tested against the most sensitive bacteria ( $S$. aureus). The results have revealed that only one fraction showed an antibacterial activity. This active fraction was analyzed by liquid chromatography coupled with mass spectrometry (LC/MS) in order to obtain the elemental composition of the present compounds. The molecular ions fragmentation (LC/ MS/MS) were used to determine the deployed formula of these compounds. The analysis of the results by Xcalibur 2.2 software reveals the presence of 24 molecules, and this, based on the retention times of the peaks obtained in the chromatogram, where, the $\mathrm{m} / \mathrm{z}$ ratios, the formulas, as well as the intensities of the various compounds detected are determined.
\end{abstract}

Keywords: A. quadrilineatus (MH109538), bioactive metabolites, chromatographic techniques

\section{INTRODUCTION}

Faced with the loss of antibiotic therapy effectiveness, threaten by the emergence of multiresistant germs, the discovery of new molecules has become an absolute necessity (Berger Savin, 2014). The fields of investigation are vast. However, natural resources are exploited again to lead to the discovery of new bioactive molecules reservoirs, consisting in exploring these molecules especially from microorganisms. Fungi are among the best candidates for the production of biologically active secondary metabolites. This group of microorganisms is responsible for around $22 \%$ of active molecules with antibacterial effect produced on an industrial scale (Atoui, 2006). Indeed, the species of Aspergillus genus prove to be a true metabolic factories responsible for the synthesis of chemical compounds plethora (Youcef Ali, 2014), including substances with antibacterial effect (Madki et al., 2010 ; Barakat \& Gohar, 2012 ; Al-Shaibani et al., 2013 ; Liu et al.,

*Author for correspondence: Amina Bramki, Laboratory of Mycology, Biotechnology and Microbial Activity, University of Mentouri BrothersConstantine, Algeria. Email - br_amina@yahoo.fr 
2017). For this reason, the fungal specie $A$. quadrilineatus (MH109538), isolated from soil taken from an arid zone (Laghouat; located at 400 $\mathrm{km}$ south of Algiers) has been screened to see its activity towards sensitive and resistant bacteria (primary screening). In order to analyze and characterize these bioactive metabolites, usually present as traces in the crude extract, a whole range of methods was used essentially based on the principle of molecules chromatographic separation, then their detection with spectrometry.

\section{MATERIALS AND METHODS}

\section{Preparation of the crude extract}

The used fermentation medium was Czapek dox supplemented with $2.5 \mathrm{~g} / \mathrm{L}$ of yeast extract. 500 $\mathrm{mL}$ flasks, containing $100 \mathrm{~mL}$ of liquid culture medium, were inoculated with eight disks of seven days aged culture. After 14 days of incubation at $28^{\circ} \mathrm{C}$, an identical volume of chloroform (100 $\mathrm{mL}$ ) was added to each flask containing the fungal culture, the mixture was crushed using ultra turrax, and then filtered on Whatman paper $\mathrm{N}^{\circ} 01$. After decantation, the chloroform phase was concentrated by vacuum evaporation using a Rotavapor (Gengan et al., 1999 ; Zerroug, 2011 ; Ghorri, 2015).

\section{Demonstration of the antibacterial activity Preparation of bacterial strains}

The used microbial support was composed of six bacterial strains, four ATCC strains (American Type Culture Collection), which were: Staphylococcus aureus (ATCC 25923), Bacillus subtilis (ATCC 6633), Escherichia coli (ATCC, 25922), Pseudomonas aeruginosa (ATCC, 27853), and two clinical strains namely: Enterococcus faecalis and Klebsiella pneumoniae. Antibacterial tests must be performed from young cultures (18 to $24 \mathrm{~h}$ ). The opacity of the bacterial suspensions in sterile physiological water was equivalent to 0.5 McFarland (Gonelimali et al., 2018 ; Manandhar et al., 2019).

\section{Highlight test by disks technique}

A quantity of crude extract was dissolved in dimethylsulfoxide (DMSO) in order to obtain a concentration of $100 \mathrm{mg} / \mathrm{mL}$. Then, sterile disks of $6 \mathrm{~mm}$ in diameter, prepared from Whatman paper No. 1, containing $10 \mu \mathrm{L}$ of the tested extract. After drying, the disks were carefully placed on Petri dishes containing Mueller-Hinton medium previously seeded by the tested bacteria. After that, the Petri dishes are incubated at $4^{\circ} \mathrm{C}$ in a refrigerator for $2 \mathrm{~h}$ to allow the diffusion of bioactive substances, thereafter placed in an oven at $37^{\circ} \mathrm{C}$ for 18 to 24 hours (Yamaç and Bilgili, 2008 ; Razmavar et al., 2014). It should be noted that three repetitions were performed, and the diameters of the inhibition zones were measured in millimeter.

\section{Separation of metabolites by column chromatography}

The used column measured 22 X $400 \mathrm{~mm}$ prepared according to the following process: the tube was provided at the bottom end with a grid and cotton, then filled at two-thirds with chloroform and next with $5 \mathrm{~g}$ of sodium sulfate (granular anhydrous). After checking that the top surface of the sodium sulfate layer was flooded, a quantity of $10 \mathrm{~g}$ of silica gel 60 was added, stirring carefully after each addition to remove air bubbles. The preparation was left to stand for 1 hour, and then $15 \mathrm{~g}$ of sodium sulfate were added carefully, thus forming the upper layer of the column. The chloroform excess was eliminated through the lower tube track placed for this purpose. $50 \mathrm{~mL}$ of chloroform extract were added to $100 \mathrm{~mL}$ of hexane, then, the mixture was quantitatively transferred to the column with the elimination of the elapsed liquid. Afterwards, a volume of $100 \mathrm{~mL}$ of diethyl ether was added and allowed to descend again to the upper surface of the sodium sulfate layer. Then, the elution was carried out with $150 \mathrm{~mL}$ of mixture (chloroform methanol: 97/3 V/V) (Zinedine, 2004; Abdelaziz, 2006).

\section{Thin layer chromatography (TLC)}

After column fractionation, the bioactive molecules were separated again by TLC, which was carried out on silica gel plates $\ll 60 \mathrm{~F} 254$ 》. A volume of almost $200 \mu \mathrm{L}$ of each fraction was gradually deposited, using capillary in the form of spots. The atmosphere of the tank was saturated previously by a mobile phase consisting of three solvents (Toluene / Ethyl acetate / Formic acid; 
50/40/10) (Siddiqui, 2004; Awad, 2005). After migration, the plates were dried then visualized under UV light ( $\lambda=254$ and $365 \mathrm{~nm}$ ) (Móricza et al., 2016). The spots that appeared were scraped and deposited on the surface of the Mueller Hinton medium seeded with the most sensitive test bacteria ( $S$. aureus) to demonstrate their antibacterial activity. Afterwards, the Petri dishes were placed at $4^{\circ} \mathrm{C}$ for $4 \mathrm{~h}$ to allow the diffusion of bioactive substances, and then incubated at $37^{\circ} \mathrm{C}$ for 18 to $24 \mathrm{~h}$ (Boughachich, 2012).

\section{Analysis by (LC/MS) and (LC/MS/MS)}

The active fraction was scraped, suspended in 3 $\mathrm{mL}$ of chloroform and subjected to a rotary mixer for $1 \mathrm{~h}$. After centrifugation at $15000 \mathrm{~g}$ for $5 \mathrm{~min}$, the supernatant was collected and evaporated to dryness using a vacuum ramp. Then the fraction was resuspended in $500 \mu \mathrm{L}$ of water/methanol mixture $(97.5 \% ; 2.5 \%)$, then filtered on a $0.45 \mu \mathrm{m}$ millipore membrane so that it can be analyzed.

The used chromatographic system was composed of a binary pump system in order to generate a gradient, two columns (a preconcentration column and an analytical column) and an injector. The different elements were connected to a computer, allowing the different components of the chromatographic system to be controlled automatically.

$4 \mu \mathrm{L}$ of filtered extract was automatically injected into the device; Acquity M-Class UPLC class (Waters, Milford, MA, USA) connected to a Q Exactive (Thermo Scientific, Bremen, Germany). The sample was loaded on a trap column (Symmetry C18 $5 \mu \mathrm{m}, 180 \mu \mathrm{m}$ x $20 \mathrm{~mm}$, Waters) in $100 \%$ of solvent A (Water with $0.1 \%$ formic acid) for $3 \mathrm{~min}$, and then separated on the analysis column (HSS T3 C18 1,8 $\mu \mathrm{m} .75 \mu \mathrm{m} x$ $250 \mathrm{~mm}$, Waters) with a flow rate of $600 \mathrm{~nL} / \mathrm{min}$. A solvent gradient system was applied in order to separate the secondary metabolites from the used fraction. The mobile phase was composed of two solvents: solvent A (as previously described) and solvent B (Acetonitrile with $0.1 \%$ formic acid). Table 1 represents the used linear gradient program.

\section{Operating conditions of ionization parameters (LC-ESI-MS and LC/MS/MS)}

The UPLC device was coupled to a Q-Exactive (Thermo Scientific, Bremen, Germany), in positive ion mode to a nano-electrospray - MS with an Orbitrap type analyzer. The system was controlled by Xcalibur 2.2 software (Thermo Fisher Scientific). The recorded data with an $\mathrm{m} / \mathrm{z}$ ratio of 80 to 1200 were then analyzed using the full MS scan mode.

Table 1. Gradient program used for the analysis and separation of metabolites.

\begin{tabular}{ccc}
\hline $\begin{array}{c}\text { Time (min) } \\
\text { Solvent }\end{array}$ & A & B \\
\hline $0 \mathrm{~min}$ & $98 \%$ & $2 \%$ \\
$5 \mathrm{~min}$ & $93 \%$ & $7 \%$ \\
$135 \mathrm{~min}$ & $70 \%$ & $30 \%$ \\
$150 \mathrm{~min}$ & $60 \%$ & $40 \%$ \\
$154 \mathrm{~min}$ & $10 \%$ & $90 \%$ \\
$162 \mathrm{~min}$ & $98 \%$ & $2 \%$ \\
$180 \mathrm{~min}$ & $98 \%$ & $2 \%$ \\
\hline
\end{tabular}

The parameter values to obtain optimal signal-to-noise ratio, in positive mode, were as follows: A capillary voltage of $\pm 3.5 \mathrm{kV}$, a capillary temperature of $320^{\circ} \mathrm{C}$, a cone gas flow rate of 6 $\mathrm{L} / \mathrm{min}$, a target value of automatic gain control (AGC) equal to $3 \times 10^{6}$ charges, a maximum injection time of $200 \mathrm{~ms}$, with a resolution equal to 70000 .

The data were acquired in profile mode. In order to allow the metabolites identification, additional MS acquisitions were carried out using collision-induced dissociation. On the Exactive Orbitrap, the data was acquired using the DDMS2 (Data Dependent Acquisition) method (TOP 10), and the parameter values were set as follows: A collision energy "HCD" equal to 27 , a resolution equal to 17500 , a target value of the automatic gain control (AGC) equal to $1 \times 10^{5}$ charges, a maximum injection time of $200 \mathrm{~ms}$, an isolation window equal to $2 \mathrm{~m} / \mathrm{z}$. The number of MS/MS acquisition has been set to 10 for an MS spectrum (Top 10), Dynamic exclusion was set at $10.0 \mathrm{~S}$., and the Lock mass at 445.12003, with mass accuracy equal to $5 \mathrm{ppm}$.

Figure 1 summarizes the procedure of characterizing bioactive secondary metabolites of the fungal strain A. quadrilineatus (MH109538); from fermentation and extraction of fungal metabolites to LC/MS analysis of the active fraction and the comparison of results with the ChemSpider database. 
Fermentation and extraction of secondary metabolites of the fungal strain A. quadrilineatus (MH109538)

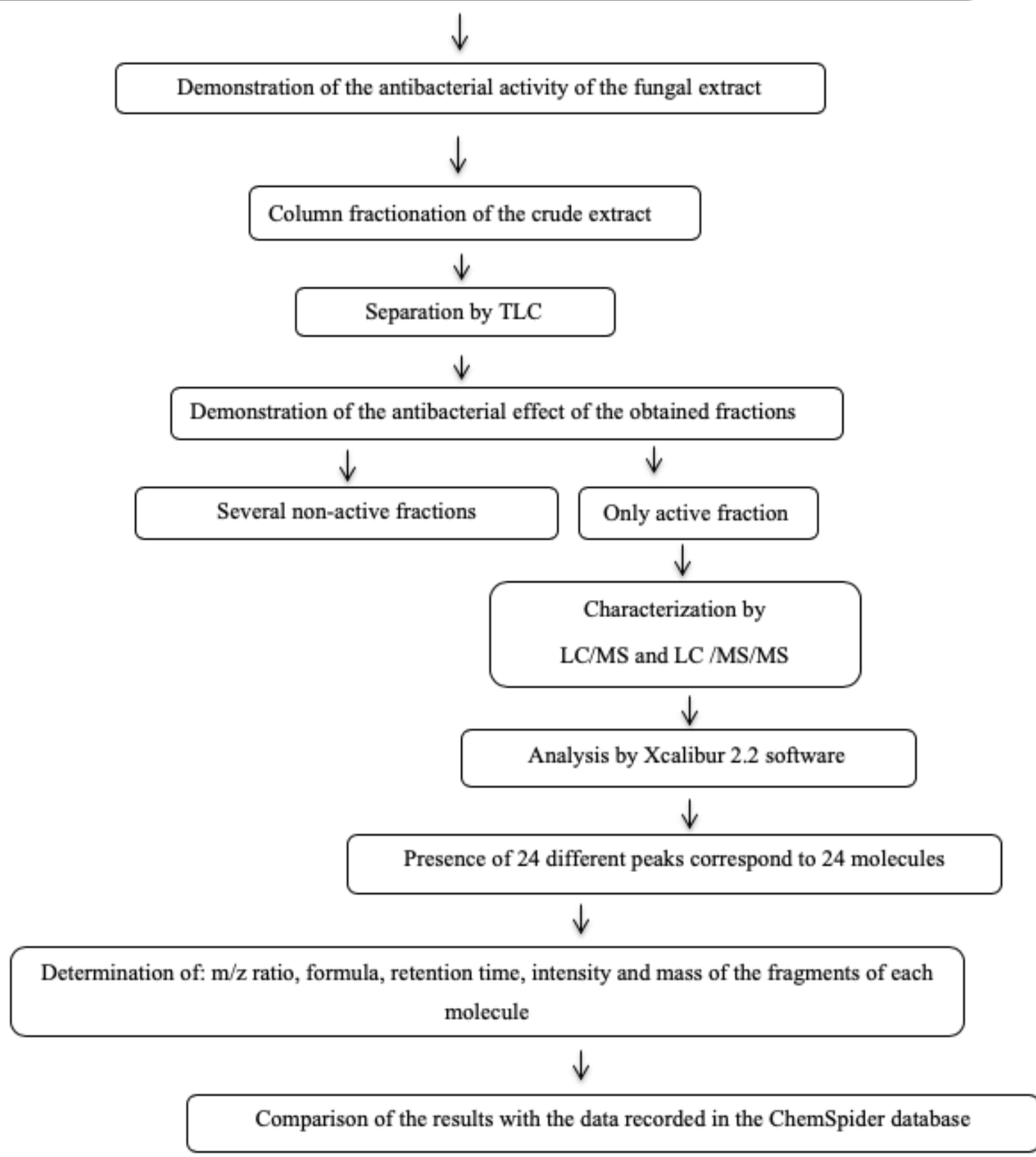

Figure 1. Process of characterizing bioactive secondary metabolites.

\section{RESULTS AND DISCUSSION}

\section{Demonstration of the antibacterial activity}

The highlight test by disks technique revealed the capacity of the fungal strain $A$. quadrilineatus (MH109538) to produce antibacterial molecules, where the most significant effects are observed against the two bacteria $S$. aureus and E. faecalis with inhibition zones diameters of 17.67 and 15.0 $\mathrm{mm}$ respectively. In contrast, the bacteria $B$. subtilis and E. coli were less sensitive to bioactive metabolites, where the recorded diameters are equal to $13.0 \mathrm{~mm}$, followed by $K$. pneumoniae with a diameter of $11.67 \mathrm{~mm}$. Otherwise, no inhibition zone was observed against the $P$. aeruginosa strain (Table 2). Our results were agree with those of Irobi et al. in 2000 (in different working conditions), whereby the $A$. quadrilineatus fungal strain has a considerable antibacterial effect 
against $B$. subtilis (with inhibition zones from 0 to $42 \mathrm{~mm}$ in diameter) and $S$. aureus (with inhibition zones from 0 to $38 \mathrm{~mm}$ in diameter). Abdelaziz in 2006, also showed that Aspergillus fungal strains had a considerable antibacterial effect against the tested bacteria. However, Aspergillus species are known by their production of antibacterial substances (Madki et al., 2010 ; Ola et al., 2014 ; Xu et al., 2015 ; Pillai et al., 2016 ; Phainuphong et al., 2017).

\section{Chromatographic separation}

In order to study the natural substances of fungal origin, different methods of analytical chemistry, aimed at detecting molecules in complex mixtures are used depending on the type of compounds and the studied matrices, often involving separated or coupled chromatographic techniques to different detection systems (Cigic and Prosen, 2009).

Within this framework, the crude extract of the fungal strain was fractionated using column chromatography. Afterwards, the molecules are separated again using the thin layer chromatographic technique. Generally, to achieve pure biomolecules, it is essential to use all these different chromatographic techniques, and at each step it is necessary to test the biological activity of the fractions. Therefore, the spots that appeared are scraped and tested against the most sensitive bacteria (S. aureus) (Boughachiche, 2012). The results reveal that only one fraction showed an antibacterial activity with inhibition zone of 14 $\mathrm{mm}$ in diameter. This active fraction has an $\mathrm{Rf}$ equal to 0.526 , and a yellow color in visible light as well as under the two wavelengths $254 \mathrm{~nm}$ and $365 \mathrm{~nm}$. In addition, this minority fraction represents almost all of the crude extract activity, which confirms our results on the other nonactive fractions. This proves that the steps applied for the separation of bioactive molecules allowed to obtain a suitably separated fraction and therefore, concentrate the active ingredient of the A. quadrilineatus (MH109538) fungal strain. In fact, several consulted studies have mentioned that thin layer chromatography is applied in most cases of secondary metabolites purification (Neilson, 2000 ; Bajpai et al., 2016).

Table 2. Demonstration of the antibacterial activity of fungal strain by the disks technique.

\begin{tabular}{ccccccc}
\hline & S. aureus & B. subtilis & E. faecalis & E. coli & P. aeruginosa & K. pneumoniae \\
\hline A. quadrilineatus & $17.67 \pm 1.53$ & $13.0 \pm 1.0$ & $15.0 \pm 2.0$ & $13.0 \pm 2.64$ & - & $11.67 \pm 1.53$ \\
\hline
\end{tabular}

*(-): Diameter of the inhibition zone $<6 \mathrm{~mm}$.

\section{Analysis by (LC/MS) and (LC/MS/MS)}

In order to identify and characterize the bioactive molecules present in the fraction, considered as pure, we used the liquid chromatography technique coupled with simple spectrometry (LC/MS) and in tandem mode (LC/MS/MS). Indeed these techniques are widely used because not only they are a detection methods often encountered for the analysis of secondary metabolites, but above all, they provide structural information on the analyzes studied (Bains and Tewani, 1987 ; Gupta et al., 1989 ; Benserradj, 2014).

In order to obtain a satisfying separation of secondary metabolites. The UPLC system was carried out in a linear elution gradient of $180 \mathrm{~min}$. Figure 2 shows the chromatographic profile obtained by UPLC analysis of the strain $A$. quadrilineatus (MH109538) active fraction. It has been observed that the secondary metabolites sought in the active fraction cover a wide range of polarity and that 180 minutes are necessary to separate all of these molecules.

In mass spectrometry, the molecule is analyzed in an ionized form and to quantify it, the detector records the intensity of the signal associated with this specie $(\mathrm{m} / \mathrm{z}$ ratio) as a function of time (Figure 3).

The analysis by Xcalibur 2.2 software (Thermo Fisher Scientific) of chromatographic peaks and MS spectra reveal the presence of 24 different peaks correspond to 24 molecules, of which the majority (very intense peaks) are those with elution times 46.05, 63.30, 76.93, 86.61, 137.90, 157.18, 157.20, 157.77, and $158.01 \mathrm{~min}$.

The different compounds detected with their $\mathrm{m} / \mathrm{z}$ ratios, their formulas (the formulas proposed are compatible with the requirements imposed on the spectrometer but these are the candidates to be checked), their retention times and their intensities are represented in Table 3. In order to identify bioactive metabolites, additional MS 
acquisitions were performed using collision induced dissociation. The masses of the different obtained fragments are represented in Table 4.

The obtained results are compared with those described in the literature (the ChemSpider database; http://www.chemspider.com), in order to achieve the determination of bioactive metabolites nature and to arrive at their identification. This comparison was based on the mass/charge ratios, the crude formulas and the pseudo-molecular ions of each compound. Indeed, ChemSpider, proposed to us for each compound, a variety of metabolites, which have the same formulas and the same masses to those obtained in our fraction.

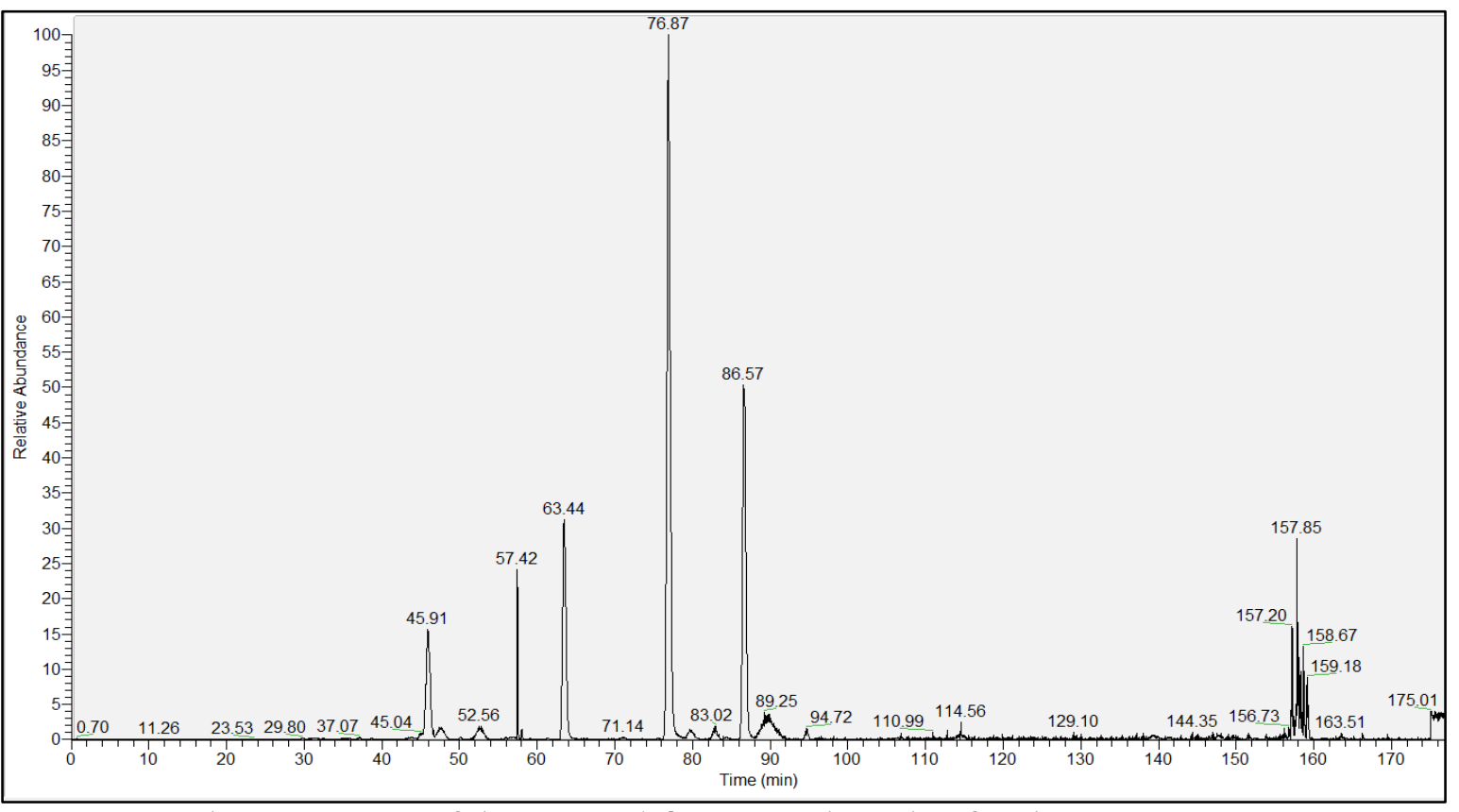

Figure 2. UPLC chromatogram of the $A$. quadrilineatus strain active fraction.

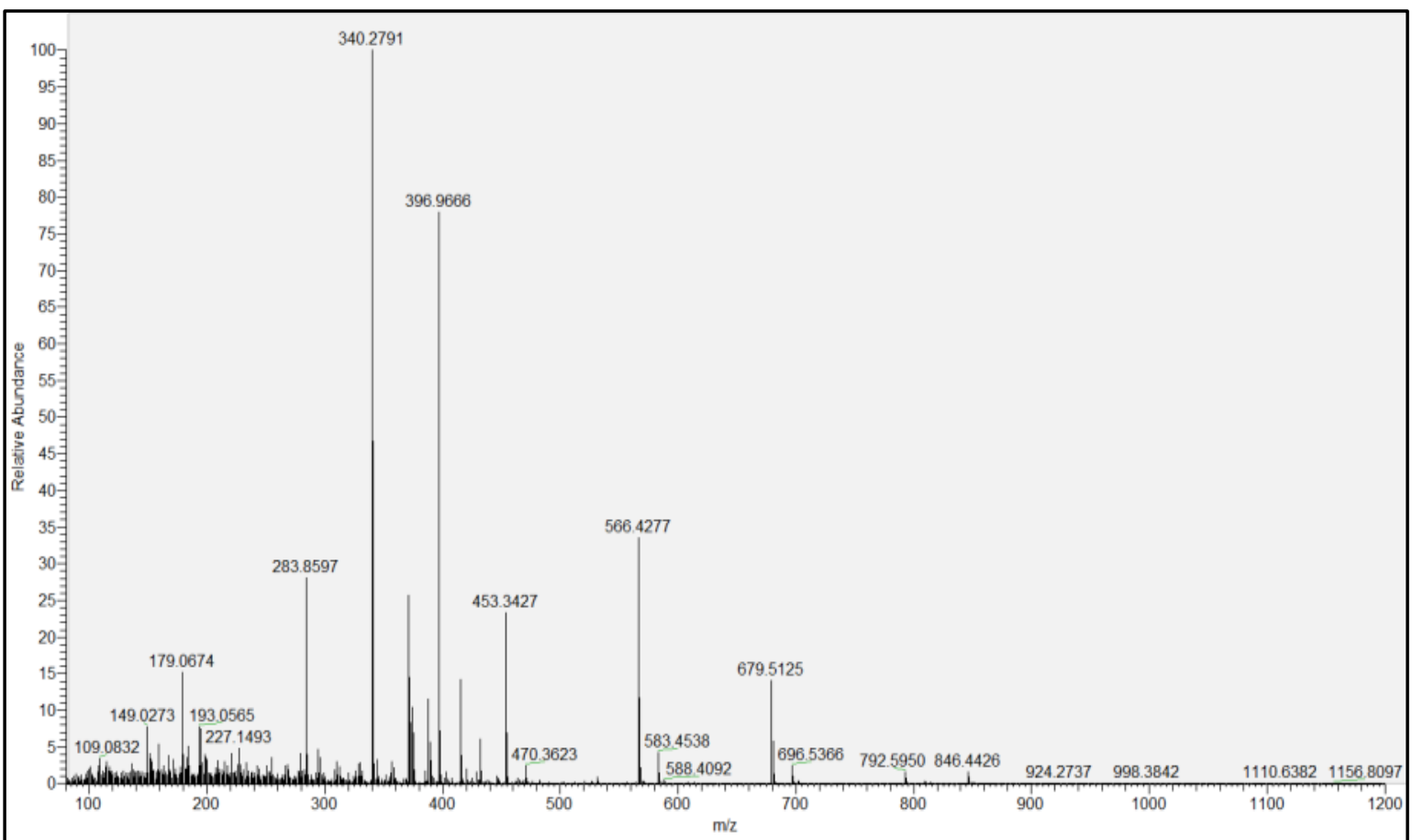

Figure 3. Sum of mass spectra obtained by ESI-MS in positive mode of the A. quadrilineatus strain active fraction. 
Table 3. The different compounds detected in the active fraction by UPLC-MS analysis.

\begin{tabular}{|c|c|c|c|c|c|}
\hline Compound & $\begin{array}{l}\text { Retention } \\
\text { time }\end{array}$ & $\mathrm{m} / \mathrm{z}$ ratio & Ion type & Formula & Intensity \\
\hline 1 & 46.05 & 453.3429 & {$[\mathbf{M}+\mathbf{H}]^{+}$} & $\mathrm{C}_{24} \mathrm{H}_{45} \mathbf{O}_{4} \mathbf{N}_{4}$ & $1.59 \times 10^{8}$ \\
\hline 2 & 63.30 & 566.4278 & {$[\mathbf{M}+\mathbf{H}]^{+}$} & $\mathrm{C}_{30} \mathrm{H}_{56} \mathrm{O}_{5} \mathrm{~N}_{5}$ & $2.73 \times 10^{8}$ \\
\hline 3 & 76.93 & 679.5119 & {$[\mathrm{M}+\mathrm{H}]^{+}$} & $\mathrm{C}_{28} \mathrm{H}_{59} \mathrm{O}_{9} \mathbf{N}_{10}$ & $1.14 \times 10^{9}$ \\
\hline 4 & 86.61 & 792.5946 & {$[\mathrm{M}+\mathrm{H}]^{+}$} & $\mathrm{C}_{38} \mathrm{H}_{74} \mathrm{O}_{5} \mathrm{~N}_{13}$ & $6.39 \times 10^{8}$ \\
\hline 5 & 137.90 & 177.546 & {$[\mathbf{M}+\mathbf{H}]^{+}$} & $\mathrm{C}_{10} \mathrm{H}_{9} \mathrm{O}_{3}$ & $4.87 \times 10^{8}$ \\
\hline 6 & 154.21 & 191.1430 & {$[\mathrm{M}+\mathrm{H}]^{+}$} & $\mathrm{C}_{13} \mathrm{H}_{19} \mathrm{O}$ & $1.20 \times 10^{7}$ \\
\hline 7 & 155.53 & 161.091 & {$[\mathrm{M}+\mathrm{H}]^{+}$} & $\mathrm{C}_{11} \mathrm{H}_{13} \mathrm{O}$ & $2.41 \times 10^{7}$ \\
\hline 8 & 155.79 & 221.1172 & {$[\mathrm{M}+\mathrm{H}]^{+}$} & $\mathrm{C}_{13} \mathrm{H}_{17} \mathrm{O}_{3}$ & $1.61 \times 10^{7}$ \\
\hline 9 & 156.16 & 242.2841 & {$[\mathrm{M}+\mathrm{H}]^{+}$} & $\mathrm{C}_{16} \mathrm{H}_{36} \mathrm{~N}$ & $1.62 \times 10^{7}$ \\
\hline 10 & 156.26 & 312.2532 & {$\left[\mathrm{M}+\mathrm{NH}_{4}\right]^{+}$} & $\mathrm{C}_{18} \mathrm{H}_{34} \mathrm{O}_{3} \mathrm{~N}$ & $1.52 \times 10^{7}$ \\
\hline 11 & 156.56 & 197.1536 & {$[\mathrm{M}+\mathrm{H}]^{+}$} & $\mathrm{C}_{12} \mathrm{H}_{21} \mathrm{O}_{2}$ & $3.44 \times 10^{7}$ \\
\hline 12 & 157.18 & 195.1015 & {$[\mathrm{M}+\mathrm{H}]^{+}$} & $\mathrm{C}_{11} \mathrm{H}_{15} \mathrm{O}_{3}$ & $1.67 \times 10^{8}$ \\
\hline 13 & 157.20 & 167.0703 & {$[\mathrm{M}+\mathrm{H}]^{+}$} & $\mathrm{C}_{9} \mathrm{H}_{11} \mathrm{O}_{3}$ & $1.09 \times 10^{8}$ \\
\hline 14 & 157.25 & 227.1639 & {$[\mathrm{M}+\mathrm{H}]^{+}$} & $\mathrm{C}_{13} \mathrm{H}_{23} \mathrm{O}_{3}$ & $7.50 \times 10^{7}$ \\
\hline 15 & 157.36 & 385.0920 & {$[\mathrm{M}+\mathrm{H}]^{+}$} & $\mathrm{C}_{20} \mathrm{H}_{17} \mathrm{O}_{8}$ & $3.21 \times 10^{7}$ \\
\hline 16 & 157.39 & 402.1179 & {$\left[\mathrm{M}+\mathrm{NH}_{4}\right]^{+}$} & $\mathrm{C}_{4} \mathrm{H}_{20} \mathrm{O}_{13} \mathrm{~N}_{9}$ & $3.25 \times 10^{7}$ \\
\hline 17 & 157.41 & 231.1590 & {$[\mathrm{M}+\mathrm{H}]^{+}$} & $\mathrm{C}_{12} \mathrm{H}_{23} \mathrm{O}_{4}$ & $2.26 \times 10^{7}$ \\
\hline 18 & 157.77 & 199.1692 & {$[\mathrm{M}+\mathrm{H}]^{+}$} & $\mathrm{C}_{12} \mathrm{H}_{23} \mathrm{O}_{2}$ & $1.06 \times 10^{8}$ \\
\hline 19 & 157.97 & 253.1798 & {$[\mathrm{M}+\mathrm{H}]^{+}$} & $\mathrm{C}_{15} \mathrm{H}_{25} \mathrm{O}_{3}$ & $6.83 \times 10^{7}$ \\
\hline 20 & 158.01 & 415.2114 & {$[\mathrm{M}+\mathrm{H}]^{+}$} & $\mathrm{C}_{9} \mathrm{H}_{27} \mathrm{O}_{7} \mathbf{N}_{12}$ & $1.51 \times 10^{8}$ \\
\hline 21 & 158.23 & 251.1492 & {$[\mathrm{M}+\mathrm{H}]^{+}$} & $\mathrm{C}_{11} \mathrm{H}_{23} \mathrm{O}_{6}$ & $1.21 \times 10^{7}$ \\
\hline 22 & 158.69 & 215.1277 & {$[\mathrm{M}+\mathrm{H}]^{+}$} & $\mathrm{C}_{11} \mathrm{H}_{19} \mathrm{O}_{4}$ & $1.01 \times 10^{7}$ \\
\hline 23 & 159.18 & 294.2062 & {$[\mathrm{M}+\mathrm{NH} 4]^{+}$} & $\mathrm{C}_{17} \mathrm{H}_{28} \mathrm{O}_{3} \mathrm{~N}$ & $7.53 \times 10^{7}$ \\
\hline 24 & 159.22 & 221.1172 & {$[\mathrm{M}+\mathrm{H}]^{+}$} & $\mathrm{C}_{13} \mathrm{H}_{17} \mathrm{O}_{3}$ & $4.54 \times 10^{7}$ \\
\hline
\end{tabular}

For example; the database proposed five different metabolites (cyclic peptides) for the second compound (Tr: 63.30). Therefore, the identification confirmation of these metabolites requires: either the use of standards (pure molecules), by comparison of the chromatograms and mass spectra of these standards with those obtained in our fraction, which must have a similarity in the retention times, the molecular weights and the molecular weights of the fragments, with our obtained compounds, or the use of other spectrometric identification techniques such as nuclear magnetic resonance (NMR of proton and carbon 13) which studies the evolution of a spin system specific to each nucleus subjected to a magnetic field (Silverstein et al., 2007).

This technique will be complementary to the results already obtained and can help in structure determination. Indeed, the secondary metabolites of natural origin (vegetable, marine, fungal or bacterial), have characteristics making their study a little difficult such as; the very small amount of the active ingredient, often with mixtures of molecules with close structures making the extraction and purification steps long and which can also lead to antagonistic or synergistic effects between the molecules (Garneau et al., 2002). 
Table 4. The different compounds detected with their MS/MS fragments.

Compound MS/MS Fragment Masses

\begin{tabular}{|c|c|}
\hline 1 & $\begin{array}{c}435.3324,417.0467,340.2583,322.2482,284.1721,209.1645,114.0914, \quad 96.0809, \\
69.0699\end{array}$ \\
\hline 2 & $\begin{array}{c}548.4172,453.3443,435.3332,341.2424,322.2491,228.1596,209.1650,114.0906, \\
96.0813\end{array}$ \\
\hline 3 & $\begin{array}{c}661.5021,566.4319,548.4182,452.3597,435.3335,341.2438,322.2492,228.1594, \\
209.1652,114.0919,96.0813\end{array}$ \\
\hline 4 & $\begin{array}{c}\text { 774.5840, 679.5123, 661.4995, 548.4176, 452.3607, 435.3329, 341.2442, 322.2490, } \\
228.1590,209.1650,114.0915,96.0810\end{array}$ \\
\hline 5 & $149.0233,121.0285$ \\
\hline 6 & $149.0961,135.0805,121.0651,107.0495$ \\
\hline 7 & $146.0727,133.1012,105.0703$ \\
\hline 8 & $179.1067,161.0961$ \\
\hline 9 & $181.1222,155.0702,130.1590,87.0810,71.0862,57.0706$ \\
\hline 10 & $295.2267,277.2162,259.2054,165.1274,113.0964,85.1017$ \\
\hline 11 & $179.1432,151.1483,141.0911,123.0807,95.0860,57.0707$ \\
\hline 12 & $167.0703,149.0598,123.0807,95.0496$ \\
\hline 13 & $149.0598,139.0390,121.0286,95.0496$ \\
\hline 14 & $209.1533,177.1273,149.1325,135.1169,107.0859,97.0651,93.0703,79.0548$ \\
\hline 15 & $359.0761,341.0658,237.0760,193.0497,149.0234$ \\
\hline 16 & $385.0914,359.0753,341.0649,237.0760,193.0493$ \\
\hline 17 & $171.1017,147.0653,129.0548,111.0444,101.0601$ \\
\hline 18 & $181.1590,163.1482,153.1640,111.1172,107.0859,97.1017,83.0861,69.0706,55.0550$ \\
\hline 19 & $197.1174,179.1066,141.0547,123.0442,97.0290,57.0707$ \\
\hline 20 & $135.0805,119.0858$ \\
\hline 21 & $211.0816,193.0710,171.0139,153.0033$ \\
\hline 22 & 71.0499 \\
\hline 23 & $221.1172,203.1066,175.1117,165.0546,161.0960,57.0706$ \\
\hline 24 & $203.1079,193.1233,179.1075,175.1125,165.0554,161.0968,137.0603,57.0709$ \\
\hline
\end{tabular}

\section{CONCLUSION}

To analyze the metabolites with antibacterial effect present in the crude extract of the $A$. quadrilineatus fungal strain (MH109538), a molecules separation was used by chromatographic techniques. The antibacterial effect test of the different spots has proven the activity of only one fraction. After the analysis of this fraction by UPLC-MS, 24 peaks corresponding to 24 molecules were revealed with determination of their chemical characteristics: $\mathrm{m} / \mathrm{z}$ ratios, formulas, retention times and intensities.

In perspective, this work is a preliminary step for broader studies, more in-depth and more accomplished including; the purification and identification of bioactive metabolites produced by this fungal strain, and in cases where these molecules turned out to be new, additional studies should be considered, such as: In vivo toxicity study, the determination of the action mechanism of these substances, as well as optimizing the biosynthesis of these bioactive molecules for medical purposes.

\section{REFERENCES}

Abdelaziz, W. 2006. Isolement des mycètes producteurs des substances antibactériennes à partir des sols sahsriens. UFMC.

Al-Shaibani, A. B. A., Al-Shakarchi, F. I., \& Ameen, R. S. 2013. Extraction and characterization of antibacterial compound from Aspergillus niger. Journal of Al-Nahrain University 16 (4):167-174. 
Atoui, A. 2006. Approche de la mycotoxinogenese chez Aspergillus ochraceus et Aspergillus carbonarius : études moléculaire et physiologique. INP. Toulouse.

Awad, G. 2005. Caractérisation et étude de l'effet des sources de carbone et d'azote sur la production de nouveaux métabolites secondaires chez Aspergillus ochraceus non producteur de l'ochratoxine A. INP. Toulouse.

Bains, P. S. \& Tewari, J. P. 1987. Purification, chemical characterization and hostspecificity of the toxin produced by Alternaria brassicae. Physiological and Molecular Plant Pathology $30: 259-271$.

Bajpai, V. K., Majumder R., \& Park, J. G. 2016. Isolation and purification of plant secondary metabolites using columnchromatographic technique. Bangladesh Journal of Pharmacology 11: 844-848.

Barakat, K. M. \& Gohar, Y. M. 2012. Antimicrobial agents produced by marine Aspergillus terreus var. africanus against some virulent fish pathogens. Indian Journal of Microbiology 52(3): 366-372.

Benserradj, O. 2014. Evaluation de Metarbiżium anisopliae à titre d'agent de lutte biologique contre les larves de moustiques. UFMC.

Berger Savin, M. C. E. 2014. La phagothérapie : historique et potentielle utilisation contre les infections à bactéries multirésistantes. FMC.

Boughachiche, F. 2012. Étude de molécules antibiotiques secrétées par des souches appartenant au genre Streptomyces, isolées de Sebkha. UFMC.

Cigic, I. K. \& Prosen, H. 2009. An overview of conventional and emerging analytical methods for the determination of mycotoxins. International Journal of Molecular Sciences 10: 62115.

Garneau, S., Martin, N. I., \& Vederas, J. C. 2002. Two-peptide bacteriocins produced by lactic acid bacteria. Biochimie 84 : 577-592.

Gengan, R. M., Chuturgoon, A. A., Mulholland D. A., \& Dutton, M. F. 1999. Synthesis of sterigmatocystin derivatives and their biotransformation to aflatoxins by a blocked mutant of Aspergillus parasiticus. Mycopathologia 144: 115-122.

Ghorri, S. 2015. Isolement des microorganismes possédant une activité anti- Fusarium. UFMC.

Gonelimali, F. D., Lin, J., Miao, W., Xuan, J., Charles, F., Chen, M., \& Hatab, S. R. 2018. Antimicrobial properties and mechanism of action of some plant extracts against food pathogens and spoilage microorganisms. Frontiers in Microbiology 9: 1-9.

Gupta, S., Roberts, D. W., \& Renwick, J. A. A. 1989. Insecticidal cyclodepsipeptides from Metarbizium anisopliae. Journal of the Chemical Society Perkin Transactions 1: 2347-2357.

Irobi, O. N., Gbodi, T. A., Moo-Young, M., \& Anderson, W. A. 2000. Antibiotic activity of Aspergillus quadrilineatus extracts isolated from a Nigerian cereal. Pharmaceutical Biology 38(1): 57-60.

Liu, S., Wang, H., Su, M., Hwang, G. J., Hong J., \& Jung, J. H. 2017. New metabolites from the sponge-derived fungus Aspergillus sydowii J05B-7F-4. Natural Product Research: 1-5.

Madki, M. A., Manzoor, A. S., Powar P. V., \& Patil, K. S. 2010. Isolation and biological activity of endophytic fungi from Withania somnifera. International Journal of Pharmaceutical Sciences 2: 848-858.

Manandhar, S., Luitel, S., \& Dahal, R. K. 2019. In vitro antimicrobial activity of some medicinal plants against human pathogenic bacteria. Journal of Tropical Medicine: 1-5.

Móricza, Á. M., Horváthb, G., Böszörményic, A., \& Otta, P. G. 2016. Detection and identification of antibacterial and antioxidant components of essential oils by TLCbiodetection and GC-MS. Natural Product Communications 11(11): $1705-1708$.
Neilson, K. F. 2000. Mould growth on building materials secondary metabolites. Mycotoxins and Biomakers.

Ola, A. R. B., Debbab, A., Aly, A. H., Mandi, A., Zerfass, I., Hamacher, A., Kassack, M. U., Brötz-Oesterhelt , H., Kurtan, T., \& Proksch, P. 2014. Absolute configuration and antibiotic activity of neosartorin from the endophytic fungus Aspergillus fumigatiaffinis. Tetrahedron Letters 55(5): $1020-1023$

Phainuphong, P., Rukachaisirikul, V., Tadpetch, K., Sukpondma, Y., Saithong, S., Phongpaichit, S., Preedanon, S., \& Sakayaroj, J. 2017. \- Butenolide and furanone derivatives from the soil-derived fungus Aspergillus sclerotiorum PSURSPG178. Phytochemistry 137: 165- 173.

Pillai, V. R., Gunasekaran, S., Ramanathan, S., Murugaiyah, V., Samsudin, M. W., \& Din, L. B. 2016. Biological activities of four Parmotrema species of Malaysian origin and their chemical constituents. Journal of Applied Pharmacentical Science. 6(08): 036-043.

Razmavar, S., Abdulla, M. A., Binti Ismail, S., \& Hassandarvish, P. 2014. Antibacterial Activity of Leaf Extracts of Baeckea frutescens against Methicillin-Resistant Staphylococcus aureus. BioMed Research International: 1-5.

Siddiqui, I. A., Shaukat, S. S., \& Khan, A. 2004. Differential impact of some Aspergillus species on Meloidogyne javanica biocontrol by Pseudomonas fluorescens strain CHA0. Letters in Applied Microbiology 39: 74-83.

Silverstein, R. M., Webster, F. X., \& Kiemle, D. J. 2007. Identification spectrometrique de composés organiques. De Boeck \& Larcier Edition, Bruxelles: 70-110.

Xu, L., Meng, W., Cao, C., Wang, J., Shan, W., \& Wang, Q. 2015. Antibacterial and antifungal compounds from marine fungi. Marine Drugs 13: 3479-3513.

Yamaç, M. \& Bilgili, F. 2008. Antimicrobial activities of fruit bodies and/or mycelial cultures of some mushroom isolates. Pharmacentical Biology 44: 660- 667.

Youcef-Ali, M. 2014. Etude de l'activité anti-Candida albicans des microorganismes isolés à partir du sol des zones arides. UFMC.

Zerroug, A. 2011. Métabolites secondaires bioactifs des champignons endophytes isolés de Retama raetam (Forssk). UFAS.

Zinedine, A. 2004. Détermination des mycotoxines dans les aliments et étude de la réduction des Aflatoxines par les bactéries lactiques isolées des ferments panaires traditionnels. USMBA. 